\title{
Lambs Weaned Early onto a Herb-Clover Mix Have the Potential to Grow at a Similar Rate to Unweaned Lambs on a Grass-Predominant Pasture
}

\author{
Lukshman Jay. Ekanayake* $*$, Rene Anne Corner-Thomas, Lydia Margaret Cranston, \\ Paul Richard Kenyon and Stephen Todd Morris \\ School of Agriculture and Environment, Private Bag 11-222, Massey University, \\ Palmerston North 4442, New Zealand; R.Corner@massey.ac.nz (R.A.C.-T.); L.Cranston@massey.ac.nz (L.M.C.); \\ P.R.Kenyon@massey.ac.nz (P.R.K.); S.T.Morris@massey.ac.nz (S.T.M.) \\ * Correspondence: jayampathiekn@gmail.com; Tel.: +64-21-103-2529; Fax: +64-6-350-5636
}

Received: 10 March 2020; Accepted: 1 April 2020; Published: 2 April 2020

check for updates

Simple Summary: Early weaning of lambs may be a useful management tool when either herbage quality or quantity limits lamb growth. Herb-clover mixes containing chicory, plantain, red clover, and white clover have been shown to improve the growth of suckling lambs and those weaned at a traditional age compared to grass-predominant pastures in New Zealand. In this study, lambs were weaned at a minimum live weight of $14 \mathrm{~kg}$ and their liveweight gains at a conventional weaning age ( $\sim 99$ days of age) were compared with lambs unweaned on a grass-predominant pasture. We found that lambs weaned early onto a herb-clover mix have the potential to achieve live weights similar to lambs unweaned on grass-predominant pasture.

\begin{abstract}
Liveweight gain of lambs weaned early at a minimum live weight of $14 \mathrm{~kg}$, at $\sim 50$ days of age, onto a herb-clover mix was compared with lambs that remained unweaned on a grass-predominant pasture or a herb-clover mix until conventional weaning (at $~ 99$ days of age). Over two years, twin sets of lambs that had a minimum live weight of $14 \mathrm{~kg}$ were randomly allocated to one of three treatments: (1) Early weaning of lambs onto a herb-clover mix $\left(\mathrm{Herb}_{\mathrm{EW}}\right)$; (2) ewes and lambs grazing a herb-clover mix until conventional weaning $\left(\mathrm{Herb}_{\mathrm{CW}}\right)$; and (3) ewes and lambs grazing a grass-predominant pasture until conventional weaning (Grass $\mathrm{CW}_{\mathrm{CW}}$ ). Herb $\mathrm{EW}_{\mathrm{EW}}$ lambs had slower $(p<0.05)$ growth rates than Grass ${ }_{\mathrm{CW}}$ lambs between early weaning and conventional weaning in 2016 and were $800 \mathrm{~g}$ lighter $(p<0.05)$ at conventional weaning. In 2017, however, both Herb $\mathrm{EW}_{\mathrm{EW}}$ and Grass $\mathrm{CW}_{\mathrm{CW}}$ had similar $(p>0.05)$ growth rates and did not differ $(p>0.05)$ in live weight at conventional weaning. Herb $\mathrm{CW}_{\mathrm{CW}}$ lambs had a greater $(p<0.05)$ growth rates than both $\mathrm{Herb}_{\mathrm{EW}}$ and Grass $\mathrm{CW}$ lambs in both years. Lambs weaned early onto a herb-clover mix have the potential to achieve live weights similar to lambs unweaned on grass-predominant pasture. Further research, however, is required to understand conditions under which early-weaned lambs can achieve similar live weights.
\end{abstract}

Keywords: early weaning; lamb growth; plantain; chicory; clover

\section{Introduction}

In New Zealand, herb-clover mixes containing plantain (Plantago lanceolata), chicory (Cichorium intybus), red clover (Trifolium pratense), and white clover (Trifolium repens) have been shown to increase the growth rate of both unweaned [1-3] and weaned lambs [4,5], and are commonly used by farmers [6]. Greater liveweight gains of lambs between four and eight months of age on the herb-clover mix are driven by greater nutritional quality (greater protein and metabolizable energy content and low fiber content) compared with grass-predominant pastures [4,5,7]. It is also known 
that white clover, red clover, and chicory have greater feeding values than ryegrass [8]. Further, studies indicate that chicory, red clover and plantain are preferentially grazed by lambs compared to ryegrass [9]. Lambs offered herb-clover mixes, therefore, can have greater voluntary feed intakes compared with lambs offered ryegrass pastures [10].

Early weaning of lambs at approximately 50 days of age is a potential tool that farmers can use to reduce the overall flock feed demand, by allowing ewes to cease lactating and return to a maintenance feeding levels. Lambs weaned early at a minimum live weight of $16 \mathrm{~kg}$, at approximately 60 days of age, onto a herb-clover mix have been shown to achieve similar or improved liveweight gains to a conventional weaning age compared with lambs that remained with their dam on a grass-predominant pasture [11]. It is, however, not known if lambs can be successfully weaned at a younger age ( $\sim 50$ days of age) and at minimum live weight of $14 \mathrm{~kg}$ onto a herb-clover mix and still achieve similar growth rates as unweaned lambs grazing on a grass-predominant pasture. The aim of the current study was to compare the liveweight gain of lambs weaned early at approximately 50 days of age, at a minimum live weight of $14 \mathrm{~kg}$, onto a herb-clover mix with lambs who remained unweaned on a herb-clover mix or grass-predominant pasture. It was hypothesized that lambs weaned early onto a herb-clover mix could achieve similar growth rates to unweaned lambs on grass-predominant pasture.

\section{Materials and Methods}

\subsection{Herbage Treatments}

Eight paddocks (13.85 ha in total land area) of herb-clover mix containing plantain, chicory, red clover, white clover, and seven paddocks ( 15.85 ha in total land area) of grass-predominant pasture (perennial ryegrass (Lolium perenne L.) and white clover) were used for the duration of the study in both years (2016 and 2017). During the experimental period (August to December), both herbage types were managed using rotational grazing to provide ad-libitum intakes such that post-grazing sward surface heights were maintained at a minimum of five $\mathrm{cm}$ in the grass-predominant pasture and seven $\mathrm{cm}$ in the herb-clover mix $[7,12]$.

\subsection{Experimental Design}

This study was conducted at Massey University's Keeble farm, $5 \mathrm{~km}$ southeast of Palmerston North, New Zealand $\left(40^{\circ} 24^{\prime} \mathrm{S}\right.$ and $\left.175^{\circ} 36^{\prime} \mathrm{E}\right)$ and replicated over two consecutive springs. All manipulations were approved by the Massey University Animal Ethics Committee (MU AEC17/40). Romney ewes that had conceived during a 17-day breeding period and diagnosed as twin bearing using transabdominal ultrasound were selected for the study. Throughout the gestation period, within each year, ewes were managed as a single flock (group) under commercial pastoral farming conditions as part of a larger flock on grass-predominant pastures.

Lambing began on 26th of August in 2016 and 28th of August in 2017. All lambs were weighed, ear tagged, and identified to their dam within $24 \mathrm{~h}$ of birth. In each year, lambs and ewes were managed as a single mob on a grass-predominant pasture from the start of lambing (L0) until the start of the study (L53 in 2016 and L51 in 2017). According to veterinary advice, lambs were drenched (1 mL per $5 \mathrm{~kg}$ live weight) with an oral triple combination drench (Matrix, Merial Ancare, Manukau City, New Zealand) at L26 in 2016 and L25 in 2017 and thereafter at 28-day intervals throughout the study to control internal parasites.

Twin rearing ewes ( $n=75$ in 2016 and $n=61$ in 2017) with twin sets of lambs of which both had a minimum live weight of $14 \mathrm{~kg}$ at L50 in 2016 (range 14.2 to $22.5 \mathrm{~kg} ; \mathrm{n}=150$ ) and at L48 in 2017 (range 14.0 to $24.0 \mathrm{~kg} ; \mathrm{n}=122$ ) were allocated to one of three treatments: (1) Early weaning of lambs at $\sim 50$ days of age onto a herb-clover mix (Herb $\mathrm{EW}, \mathrm{n}=54$ in 2016 and $\mathrm{n}=46$ in 2017); (2) ewes and lambs grazing a herb-clover mix until conventional weaning at $\sim 99$ days of age (Herb $\mathrm{CW}_{\mathrm{W}}, \mathrm{n}=46$ in 2016 and $\mathrm{n}=42$ lambs in 2017); and (3) ewes and lambs grazing a grass-predominant pasture until conventional weaning ( $\mathrm{Grass}_{\mathrm{CW}}, \mathrm{n}=50$ in 2016 and $\mathrm{n}=34$ lambs in 2017). Lambs were allocated to treatments using 
a stratified sampling procedure, based on the live weights of lambs, in order minimize the differences of average lamb live weights between groups.

Lambs and ewes allocated to treatments were managed as a single group on a grass-predominant pasture from the start of lambing (L0) until the start of the study (L53 in 2016 and L51 in 2017). Beginning at L50 in 2016 and L48 in 2017, Herb $\mathrm{EW}_{\mathrm{EW}}$ or Herb $\mathrm{CW}_{\mathrm{CW}}$ lambs were gradually introduced to herb-clover mix over a four-day period by increasing the duration on the herb-clover mix each day (i.e., $4 \mathrm{~h}$ day $1,8 \mathrm{~h}$ day $2,12 \mathrm{~h}$ day 3 , and $24 \mathrm{~h}$ day 4), prior to the start of the main study. At L50 in 2016 and at L48 in 2017, average live weights of lambs were similar among treatments $(17.1 \pm 0.8,17.3 \pm 0.6$, $16.9 \pm 0.4 \mathrm{~kg}$ in Herb $\mathrm{EW}, \mathrm{Herb}_{\mathrm{CW}}$, and Grass $\mathrm{CW}_{\mathrm{W}}$ in 2016, and $17.9 \pm 1.5,18.4 \pm 1.3,18.6 \pm 1.1 \mathrm{~kg}$ in Herb $_{\mathrm{EW}}$, Herb $_{\mathrm{CW}}$, and Grass $\mathrm{CW}$ in 2017, respectively). The study began at L53 and L51 in 2016 and 2017, respectively. Once early weaning had been conducted the ewes in the Herb $\mathrm{EW}_{\mathrm{EW}}$ treatment were managed with Grass $\mathrm{CW}$ ewes and lambs on grass-predominant pasture to L99 in both years. Lambs in the Herb $\mathrm{EW}_{\mathrm{EW}}$ treatment were managed with $\mathrm{Herb}_{\mathrm{CW}}$ ewes and lambs on herb-clover mix to L99 in both years. Ewes develop an exclusive bond with their lambs within 1 to $2 \mathrm{hr}$ of birth and avoid fostering alien lambs for the remainder of the lactation [13]. Therefore, it is unlikely that Herb $b_{C W}$ ewes would have allowed Herb $\mathrm{EW}_{\mathrm{E}}$ lambs to suck milk.

\subsection{Animal Measurements}

Lambs and ewes were weighed within $1 \mathrm{~h}$ of removal from herbage at L53, L65 and L99 in 2016 and L51, L65 and L99 in 2017. Ewe body condition score (BCS), scale 1-5 including half units [14], was assessed at each weighing by a single operator.

\subsection{Herbage Measurements}

Herbage masses were measured at L47, L65 and L99 in both years of the study. Four random quadrat cuts $\left(0.1 \mathrm{~m}^{2}\right.$ each) were taken to ground level from herb-clover mix and grass-predominant pasture at each sampling date using an electric shearing hand-piece [15]. Samples were then oven dried to a constant weight to estimate herbage mass. In addition, four composite herbage samples each containing ten grab samples per herbage type, were also collected at each sampling date to determine the botanical and nutritional composition [15]. To determine the botanical composition of the herbage, a subsample from each composite sample (four per herbage type) was sorted into each species (herb-clover mix: plantain, chicory, red clover, white clover; grass-predominant pasture: ryegrass, clover; other grasses (combined), weeds, and dead matter) and then oven dried and weighed to determine the botanical composition. The remaining sample was then frozen, dried, ground, sieved $(1 \mathrm{~mm})$ and analyzed using in vitro methods to determine the nutritional quality. These measures included dry matter digestibility (DMD, [16]), percentage crude protein (CP; "Dumas" procedure, AOAC method 968.06 using a Leco total combustion method, LECO Corporation, St. Joseph, MI, USA). Percentage acid detergent fiber (ADF) was analyzed by a Tecator Fibretec System [17]. Metabolizable energy (ME) content of herbages was calculated from the organic matter digestibility $(\mathrm{DOMD} \times 0.16 \mathrm{MJ} / \mathrm{Kg} \mathrm{DM},[16])$.

\subsection{Statistical Analysis}

Analyses were performed separately for each year due to the differences in the days on which measurements were collected, differences in climate and herbage quality, and animals used between years. The individual animal was considered as the experimental unit for the analyses. Live weight of lambs and ewes were subjected to analysis of variance for repeated measures using the MIXED procedure in SAS (Statistical Analysis System, version 9.2; SAS Institute Inc., Cary, NC, USA). The model used was a two-way interaction of treatment and measurement date to compare treatment groups. The analysis contained and tested contrasts of all treatment and date combinations in order to describe differences among treatments and across time. The model for lamb live weight included the fixed effects of weaning treatment $\left(\mathrm{Herb}_{\mathrm{EW}}, \mathrm{Herb}_{\mathrm{CW}}, \mathrm{Grass}_{\mathrm{CW}}\right)$, sex of lamb (male, female), measurement 
date and the two-way interaction of treatment and measurement date. The live weight of lambs at the start of the treatment period was included in the model as a covariate. The model for lamb liveweight gain included the fixed effects of weaning treatment and sex of lamb. The live weight of lambs at the start of the treatment period was included in the model as a covariate.

The model for ewe live weight included the fixed effects of weaning treatment and measurement date and two-way interaction of treatment and measurement date. The duration from lambing to the start of the treatments was included as a covariate. The model for ewe liveweight gain included the fixed effect of weaning treatment. The live weight of the ewe at the start of the treatment period was included in the model as a covariate. Ewe body condition score was analyzed using a Poisson distribution and logit transformation using the GENMOD procedure in SAS. The Poisson distribution was chosen as it is a nonlinear regression model for discrete outcomes. The model included the fixed effects of weaning treatment and measurement date.

Botanical composition of herbages was analyzed using the MIXED procedure in SAS. The model included fixed effects of plant species, measurement date and year. Herbage masses were analyzed using a model that included herbage type and measurement date as fixed effects. The nutritional quality data were analyzed using the MIXED procedure in a model that included the fixed effects of herbage type and measurement date. In 2016, one lamb died in each of the Herb $b_{\mathrm{EW}}$ and Herb $\mathrm{CW}_{\mathrm{CW}}$ treatments and no lambs died in 2017. In the tables presented, the number of lambs and ewes reported vary between weighing dates due to data recording errors resulting in missing data.

\section{Results}

\subsection{Botanical Composition, Herbage Mass and Nutritional Quality of Herbage}

The percentage of chicory and plantain in the herb-clover mix was greater $(p<0.05)$ in 2016 than in 2017 (Figure 1). Total clover (red clover and white clover) in the herb-clover mix did not differ $(p>0.05)$ between years. Percentage of ryegrass and total clover in the grass-predominant pasture was greater $(p<0.05)$ in 2017 than in 2016. The combined percentage of other grass species was greater $(p<0.05)$ in 2016 than in 2017.
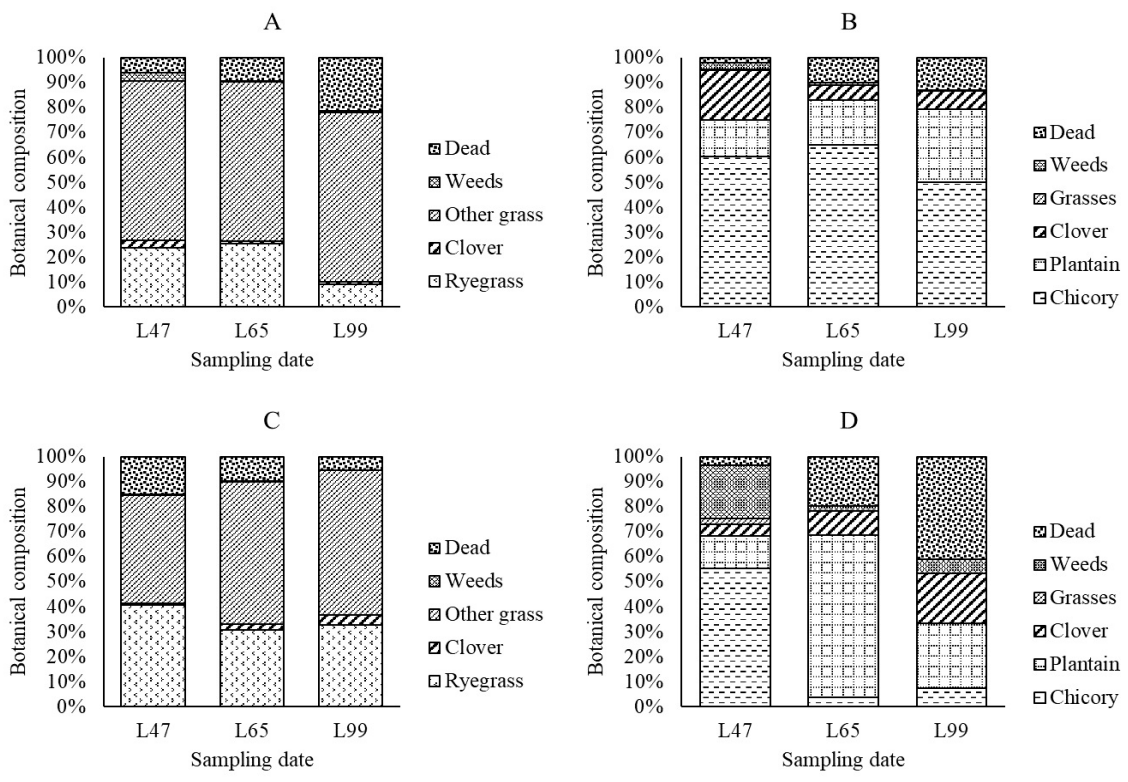

Figure 1. The botanical composition of the components of grass-predominant pasture (A), herb-clover $\operatorname{mix}(B)$ in 2016 and grass-predominant pasture (C) and herb-clover mix (D) in 2017 on 47, 65, and 99 days after the midpoint of lambing in 2016 and 2017 (L47, L65, and L99). 
In both years, the herbage mass of herb-clover mix was greater $(p<0.05)$ than that of grass-predominant pasture at the start of the study (L47, Table 1). Thereafter, herbage mass between herb-clover mix and grass-predominant pasture did not differ $(p>0.05)$.

Table 1. Herbage mass (HM), crude protein (CP), neutral detergent fiber (NDF), acid detergent fiber (ADF), dry matter digestibility (DMD), and metabolizable energy content (ME) of herbage samples collected 47, 65 and 99 days after the midpoint of lambing in 2016 and 2017 (L47, L65 and L99) (least-squares mean $\pm \mathrm{SEM}$ ).

\begin{tabular}{|c|c|c|c|c|c|c|c|}
\hline \multicolumn{2}{|l|}{ Herbage Type } & $\begin{array}{c}\text { HM } \\
\text { (kg DM/ha) }\end{array}$ & CP (\%) & NDF (\%) & ADF (\%) & DMD (\%) & $\begin{array}{c}\text { ME } \\
(\mathrm{MJ} / \mathrm{Kg})\end{array}$ \\
\hline \multicolumn{8}{|c|}{2016} \\
\hline \multirow{3}{*}{ Herb-clover mix } & L47 & $3782^{b} \pm 481$ & $21.2^{c} \pm 1.0$ & $32.1^{\mathrm{a}} \pm 2.0$ & $26.9^{a} \pm 2.3$ & $72.9^{\mathrm{e}} \pm 0.8$ & $10.6^{\mathrm{d}} \pm 0.1$ \\
\hline & L65 & $3362^{a b} \pm 481$ & $15.3^{\mathrm{a}} \pm 1.0$ & $40.8^{\mathrm{b}} \pm 2.0$ & $33.3^{\mathrm{ab}} \pm 2.3$ & $70.3^{\mathrm{d}} \pm 0.8$ & $10.2^{\mathrm{c}} \pm 0.1$ \\
\hline & L99 & $3390^{\mathrm{ab}} \pm 481$ & $13.4^{\mathrm{a}} \pm 1.0$ & $45.6^{c} \pm 2.0$ & $36.2^{b} \pm 2.3$ & $68.5^{\mathrm{d}} \pm 0.8$ & $9.8^{c} \pm 0.1$ \\
\hline \multirow{3}{*}{$\begin{array}{l}\text { Grass-predominant } \\
\text { pasture }\end{array}$} & L47 & $2362^{\mathrm{a}} \pm 481$ & $19.5^{\mathrm{b}} \pm 1.0$ & $51.0^{\mathrm{d}} \pm 2.0$ & $29.9^{\mathrm{a}} \pm 2.3$ & $65.0^{c} \pm 0.8$ & $9.2^{b} \pm 0.1$ \\
\hline & L65 & $3308^{a b} \pm 481$ & $14.3^{\mathrm{a}} \pm 1.0$ & $60.7^{\mathrm{e}} \pm 2.0$ & $39.0^{b} \pm 2.3$ & $62.4^{b} \pm 0.8$ & $8.6^{\mathrm{a}} \pm 0.1$ \\
\hline & L99 & $3270^{a b} \pm 481$ & $13.5^{\mathrm{a}} \pm 1.0$ & $62.0^{\mathrm{e}} \pm 2.0$ & $38.3^{b} \pm 2.3$ & $60.7^{a} \pm 0.8$ & $8.7^{\mathrm{a}} \pm 0.1$ \\
\hline \multicolumn{8}{|c|}{2017} \\
\hline \multirow{3}{*}{ Herb-clover mix } & L47 & $3221^{b} \pm 481$ & $17.3^{c} \pm 1.0$ & $46.7^{c} \pm 2.0$ & $26.5^{\mathrm{a}} \pm 2.3$ & $65.7^{b} \pm 0.8$ & $9.5^{\mathrm{ab}} \pm 0.1$ \\
\hline & L65 & $2994^{\mathrm{ab}} \pm 481$ & $9.8^{\mathrm{a}} \pm 1.0$ & $48.4^{c} \pm 2.0$ & $25.5^{\mathrm{a}} \pm 2.3$ & $65.4^{\mathrm{ab}} \pm 0.8$ & $9.8^{\mathrm{bc}} \pm 0.1$ \\
\hline & L99 & $3048^{b} \pm 481$ & $15.5^{b c} \pm 1.0$ & $53.7^{\mathrm{d}} \pm 2.0$ & $30.5^{b} \pm 2.3$ & $63.4^{\mathrm{a}} \pm 0.8$ & $9.1^{\mathrm{a}} \pm 0.1$ \\
\hline \multirow{3}{*}{$\begin{array}{l}\text { Grass-predominant } \\
\text { pasture }\end{array}$} & L47 & $1899^{a} \pm 481$ & $12.0^{\mathrm{a}} \pm 1.0$ & $32.7^{\mathrm{a}} \pm 2.0$ & $26.2^{\mathrm{a}} \pm 2.3$ & $72.0^{\mathrm{d}} \pm 0.8$ & $10.6^{\mathrm{d}} \pm 0.1$ \\
\hline & L65 & $2659^{a b} \pm 481$ & $10.4^{\mathrm{a}} \pm 1.0$ & $39.7^{b} \pm 2.0$ & $29.6^{\mathrm{a}} \pm 2.3$ & $68.9^{c} \pm 0.8$ & $10.1^{c} \pm 0.1$ \\
\hline & L99 & $2680^{a b} \pm 481$ & $13.0^{\mathrm{b}} \pm 1.0$ & $31.4^{\mathrm{a}} \pm 2.0$ & $23.7^{\mathrm{a}} \pm 2.3$ & $73.1^{\mathrm{d}} \pm 0.8$ & $10.6^{\mathrm{d}} \pm 0.1$ \\
\hline
\end{tabular}

${ }^{\text {a-e }}$ Means with different superscripts within columns are significantly different across years and treatments $(p<0.05)$.

In 2016, at L47, the CP content of herb-clover mix was greater $(p<0.05)$ than grass-predominant pasture. At L65 and L99, however, CP content of herb-clover mix did not differ $(p>0.05)$ from that of grass-predominant pasture (Table 1). At L47, L65 and L99, the NDF content of herb-clover mix was lower $(p<0.05)$ and DMD and ME were greater $(p<0.05)$ than that of grass-predominant pasture. The ADF content of herb-clover mix, however, did not differ $(p>0.05)$ from that of grass-predominant pasture at L47, L65 and L99.

In 2017, the CP content of herb-clover mix was greater $(p<0.05)$ than that of grass-predominant pasture at L47 but did not differ $(p>0.05)$ at L65 and L99. At L47, L65 and L99, the NDF content of herb-clover mix was greater $(p<0.05)$ and DMD was lower $(p<0.05)$ than that of grass-predominant pasture. The ADF content of herb-clover mix did not differ $(p>0.05)$ from that of grass-predominant pasture at L47 and L65 but was greater $(p<0.05)$ at L99. The ME of grass-predominant pasture was greater $(p<0.05)$ than that of herb-clover mix at L47 and L99 but was similar $(p>0.05)$ at L65.

\subsection{Lamb Live Weight and Liveweight Gain}

In 2016, the live weights of lambs in the Herb $\mathrm{EW}, \mathrm{Herb}_{\mathrm{CW}}$, and Grass $\mathrm{CW}$ treatments did not differ $(p>0.05)$ at the start of the study (L53, Table 2). At L65, the live weight of lambs in Herb $\mathrm{CW}_{\text {and }}$ Grass $_{\mathrm{CW}}$ did not differ $(p>0.05)$ but were heavier $(p<0.05)$ than lambs in Herb ${ }_{\mathrm{EW}}$. At L99, the live weight of Herb ${ }_{\mathrm{CW}}$ lambs was greater $(p<0.05)$ than Grass ${ }_{\mathrm{CW}}$ lambs, which in turn was heavier $(p<0.05)$ than Herb ${ }_{\mathrm{EW}}$ lambs. Lamb liveweight gains between L53 and L99 in Herb ${ }_{\mathrm{CW}}$ treatment were

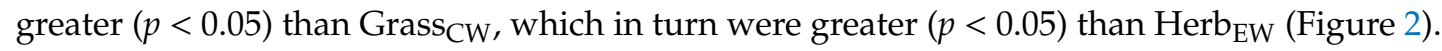


Table 2. Live weight of lambs in Herb $\mathrm{EW}_{\text {, Herb }}$ CW and Grass $\mathrm{CW}_{\mathrm{CW}}$ treatments at L53, L65 and L99 in 2016 and at L51, L65 and L99 in 2017 (least-squares mean \pm SEM).

\begin{tabular}{|c|c|c|c|c|c|c|}
\hline \multirow[t]{2}{*}{ Herbage Treatment } & \multicolumn{6}{|c|}{ Lamb Live Weight (kg) } \\
\hline & $\mathrm{n}$ & & $\mathrm{n}$ & & $\mathrm{n}$ & \\
\hline & \multicolumn{6}{|c|}{2016} \\
\hline & & L53 & & L65 & & L99 \\
\hline Herb $_{\text {EW }}$ & 54 & $19.3 \pm 0.1^{\mathrm{a}}$ & 53 & $21.5 \pm 0.2^{b}$ & 53 & $30.7 \pm 0.3^{d}$ \\
\hline Herb $_{C W}$ & 45 & $19.5 \pm 0.1^{\mathrm{a}}$ & 46 & $23.6 \pm 0.2^{c}$ & 45 & $33.2 \pm 0.4^{\mathrm{f}}$ \\
\hline \multirow[t]{3}{*}{ Grass $_{\mathrm{CW}}$} & 48 & $19.4 \pm 0.1^{\mathrm{a}}$ & 49 & $23.3 \pm 0.2^{c}$ & 50 & $31.5 \pm 0.3^{\mathrm{e}}$ \\
\hline & \multicolumn{6}{|c|}{2017} \\
\hline & & L51 & & L65 & & L99 \\
\hline Herb $_{\text {EW }}$ & 46 & $19.0 \pm 0.2^{\mathrm{a}}$ & 45 & $21.5 \pm 0.2^{b}$ & 46 & $30.5 \pm 0.4^{\mathrm{d}}$ \\
\hline Herb $_{C W}$ & 42 & $19.3 \pm 0.2^{\mathrm{a}}$ & 41 & $23.0 \pm 0.2^{c}$ & 42 & $34.5 \pm 0.4 \mathrm{e}$ \\
\hline Grass $_{\mathrm{CW}}$ & 34 & $19.1 \pm 0.2^{\mathrm{a}}$ & 33 & $22.7 \pm 0.2^{c}$ & 34 & $30.2 \pm 0.4^{\mathrm{d}}$ \\
\hline
\end{tabular}

L, days after the midpoint of lambing; Herb ${ }_{\mathrm{EW}}$, Early weaning onto unrestricted allowance of herb-clover mix; $\mathrm{Herb}_{\mathrm{CW}}$, Lambs and dams offered an unrestricted allowance of herb-clover mix until conventional weaning age; Grass $_{\mathrm{CW}}$, Lambs and dams offered unrestricted allowance of grass-predominant pasture until conventional weaning age. ${ }^{\mathrm{a}-\mathrm{f}}$ Means with different superscripts are significantly different within each year and treatments. In each year, lambs in HerbEW grazed with lambs and their ewes in HerbCW. Lambs in GrassCW grazed with both GrassCW and HerbEW ewes.

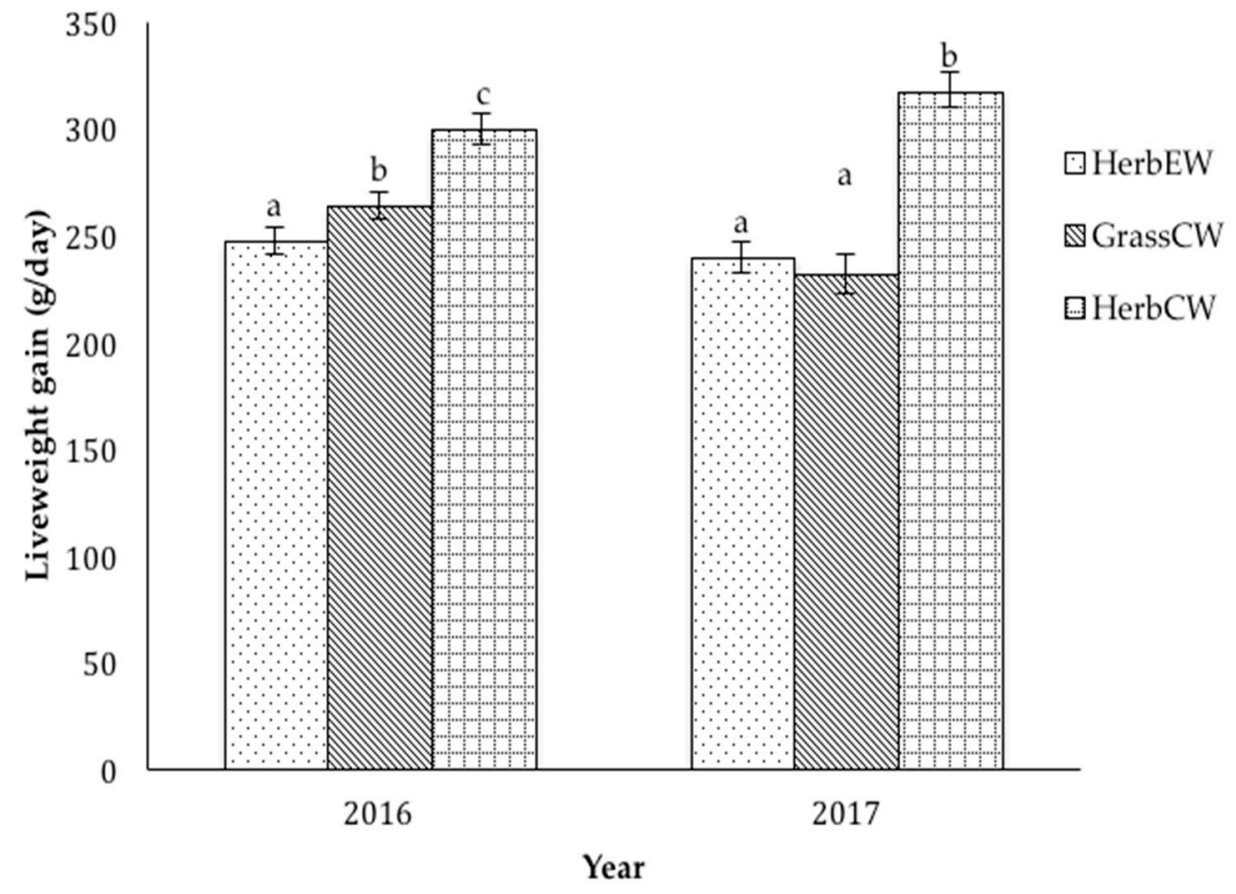

Figure 2. Liveweight gain (g/day) of lambs, from early weaning to conventional weaning, in the Herb $_{\mathrm{EW}}$, Herb $_{\mathrm{CW}}$ and Grass ${ }_{\mathrm{CW}}$ treatments in 2016 and in $2017\left({ }^{\mathrm{a}-\mathrm{c}}\right.$ means with different superscripts are significantly different within each year and treatments).

In 2017, at the start of the study (L51), the live weight of lambs in Herb $\mathrm{EW}_{\text {, Herb }}$,W, and Grass $\mathrm{CW}$ did not differ $(p>0.05)$. The live weight of lambs at L65 in Herb ${ }_{C W}$ and Grass ${ }_{C W}$ treatments did not differ $(p>0.05)$ but were heavier $(p<0.05)$ than Herb $\mathrm{EW}_{\mathrm{W}}$ lambs. At L99, the live weight of Herb $\mathrm{CW}_{\mathrm{CW}}$ lambs was greater $(p<0.05)$ than both the Herb ${ }_{\mathrm{EW}}$ and Grass $\mathrm{CW}_{\mathrm{CW}}$ lambs, which did not differ $(p>0.05)$.

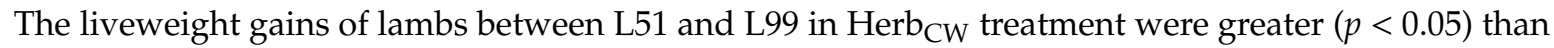
both Herb $\mathrm{EW}_{\mathrm{E}}$ and Grass ${ }_{\mathrm{CW}}$ treatments, which did not differ $(p>0.05$, Figure 2$)$. Early weaning had no 
effect on lamb survival as in 2016 one lamb died in each of the Herb $\mathrm{EW}_{\mathrm{EW}}$ and Herb $\mathrm{CW}_{\mathrm{CW}}$ treatments and no lambs died in 2017.

\subsection{Ewe Live Weight, Liveweight Gain, and Body Condition Score}

In 2016, at the start of the study (L53), the live weights of ewes in each treatment did not differ $(p>0.05)$ (Table 3). At both L65 and L99, the live weights of Herb $\mathrm{EW}_{\mathrm{EW}}$ and Herb $\mathrm{CW}_{\mathrm{CW}}$ ewes did not differ $(p>0.05)$ but were greater $(p<0.05)$ than Grass ${ }_{\mathrm{CW}}$ ewes. The liveweight gain between L53 and L99 of Herb $_{\mathrm{EW}}$ ewes $\left(192 \pm 15 \mathrm{~g} /\right.$ day) and Herb ${ }_{\mathrm{CW}}$ ewes $(173 \pm 15 \mathrm{~g} /$ day) did not differ $(p>0.05)$ but was greater $(p<0.05)$ than Grass $\mathrm{CW}$ ewes $(76 \pm 16 \mathrm{~g} /$ day $)$.

Table 3. Live weight of ewes in Herb $\mathrm{EW}_{\text {, Herb }}$ CW $_{\text {and Grass }}$ treatments at L53, L65 and L99 in 2016 and at L51, L65 and L99 in 2017 (least-squares mean \pm SEM).

\begin{tabular}{|c|c|c|c|c|c|c|}
\hline \multirow[t]{2}{*}{ Herbage Treatment } & \multicolumn{6}{|c|}{ Ewe Live Weight (kg) } \\
\hline & $\mathrm{n}$ & & $\mathrm{n}$ & & $\mathrm{n}$ & \\
\hline & \multicolumn{6}{|c|}{2016} \\
\hline & & L53 & & L65 & & L99 \\
\hline Herb $_{\mathrm{EW}}$ & 27 & $71.3 \pm 1.3^{\mathrm{a}}$ & 25 & $77.1 \pm 1.3^{b}$ & 25 & $80.3 \pm 1.3^{c}$ \\
\hline Herb $_{C W}$ & 23 & $72.2 \pm 1.4^{\mathrm{ab}}$ & 23 & $76.5 \pm 1.4^{b}$ & 23 & $80.0 \pm 1.4^{\mathrm{c}}$ \\
\hline \multirow[t]{3}{*}{ Grass $_{\mathrm{CW}}$} & 25 & $71.2 \pm 1.3^{\mathrm{a}}$ & 24 & $73.6 \pm 1.3^{a}$ & 23 & $75.1 \pm 1.4^{b}$ \\
\hline & \multicolumn{6}{|c|}{2017} \\
\hline & & L51 & & L65 & & L99 \\
\hline Herb $_{\text {EW }}$ & 23 & $67.9 \pm 1.4^{\mathrm{a}}$ & 23 & $69.2 \pm 1.4^{b}$ & 22 & $73.3 \pm 1.4^{b}$ \\
\hline Herb $_{C W}$ & 21 & $69.4 \pm 1.5^{\mathrm{ab}}$ & 20 & $70.5 \pm 1.5^{b}$ & 21 & $76.4 \pm 1.5^{\mathrm{c}}$ \\
\hline Grass $_{\mathrm{CW}}$ & 17 & $67.7 \pm 1.6^{\mathrm{a}}$ & 16 & $69.2 \pm 1.4^{\mathrm{ab}}$ & 17 & $72.4 \pm 1.6^{b}$ \\
\hline
\end{tabular}

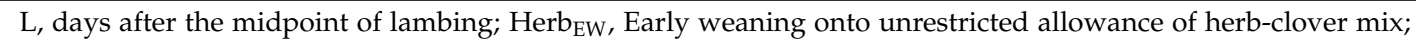
$\mathrm{Herb}_{\mathrm{CW}}$, lambs and dams offered an unrestricted allowance of herb-clover mix until conventional weaning age; Grass $_{\mathrm{CW}}$, lambs and dams offered unrestricted allowance of grass-predominant pasture until conventional weaning age. ${ }^{\mathrm{a}-\mathrm{c}}$ Means with different superscripts are significantly different within each year and treatments. In each year, ewes in Herb $b_{\mathrm{EW}}$ grazed with lambs and their ewes in Grass $\mathrm{CW}_{\mathrm{W}}$. Ewes in Herb $\mathrm{CW}_{\mathrm{CW}}$ grazed with their lambs and the weaned lambs in the Herb $\mathrm{EW}_{\mathrm{EW}}$ treatment.

In 2017, at the start of the study (L51), the live weights of ewes in each treatment did not differ $(p>0.05)$ (Table 3). At L65, ewe live weights did not differ $(p>0.05)$ between all three treatments. At L99, Herb ${ }_{C W}$ ewes were heavier $(p<0.05)$ than both Herb ${ }_{\mathrm{EW}}$ and Grass ${ }_{\mathrm{CW}}$ ewes, which did not differ $(p>0.05)$. The liveweight gains between L51 and L99 of Herb $\mathrm{EW}_{\text {ewes }}(112 \pm 16 \mathrm{~g} /$ day) and Herb $_{\mathrm{CW}}$ ewes $\left(145 \pm 17 \mathrm{~g} /\right.$ day) did not differ $(p>0.05)$ but were greater $(p<0.05)$ than Grass ${ }_{\mathrm{CW}}$ ewes (78 $\pm 19 \mathrm{~g} /$ day).

In 2016, at L53, the BCS of ewes did not differ $(p>0.05)$ between treatments (Table 4). At L65

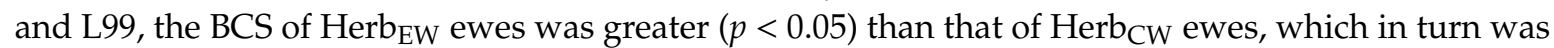
greater $(p<0.05)$ than Grass ${ }_{\mathrm{CW}}$ ewes. In 2017, at L51, BCS of ewes did not differ $(p>0.05)$ between treatments. At L65, the BCS of Herb $\mathrm{CW}_{\mathrm{C}}$ and Grass $_{\mathrm{CW}}$ ewes did not differ $(p>0.05)$ but was lower $(p<0.05)$ than Herb $\mathrm{EW}_{\mathrm{E}}$ ewes. At L99, the BCS of Herb $\mathrm{EW}_{\mathrm{EW}}$ and Herb $\mathrm{CW}_{\mathrm{C}}$ did not differ $(p>0.05)$ but was greater $(p<0.05)$ than the Grass $\mathrm{CW}$ ewes. 
Table 4. Body condition score of ewes in the Herb ${ }_{\mathrm{EW}}, \mathrm{Herb}_{\mathrm{CW}}$ and Grass $\mathrm{CW}$ treatments at L53, L65, and L99 in 2016 and at L51, L65, and L99 in 2017 (Results displayed as back transformed logit mean and $95 \%$ confidence interval).

\begin{tabular}{|c|c|c|c|c|c|c|}
\hline \multirow[t]{2}{*}{ Herbage Treatment } & \multicolumn{6}{|c|}{ Ewe Body Condition Score } \\
\hline & $\mathrm{n}$ & & $\mathrm{n}$ & & $\mathrm{n}$ & \\
\hline & \multicolumn{6}{|c|}{2016} \\
\hline & & L53 & & L65 & & L99 \\
\hline Herb $_{E W}$ & 26 & $2.3(2.2-2.4)^{\mathrm{a}}$ & 25 & $3.1(2.9-3.3)^{d}$ & 25 & $3.4(3.2-3.6)^{\mathrm{e}}$ \\
\hline Herb $_{C W}$ & 23 & $2.1(2.0-2.2)^{\mathrm{a}}$ & 23 & $2.8(2.6-2.9)^{c}$ & 23 & $3.0(2.8-3.2)^{d}$ \\
\hline \multirow[t]{3}{*}{ Grass $_{\mathrm{CW}}$} & 25 & $2.1(2.0-2.3)^{\mathrm{a}}$ & 24 & $2.5(2.4-2.6)^{b}$ & 23 & $2.5(2.4-2.7) b$ \\
\hline & \multicolumn{6}{|c|}{2017} \\
\hline & & L51 & & L65 & & L99 \\
\hline Herb $_{\text {EW }}$ & 23 & $2.9(2.8-3.1)^{\mathrm{a}}$ & 23 & $3.3(3.1-3.6)^{b}$ & 22 & $3.4(3.2-3.5)^{b}$ \\
\hline Herb $_{C W}$ & 21 & $2.7(2.5-2.9)^{\mathrm{a}}$ & 20 & $2.8(2.6-3.0)^{\mathrm{a}}$ & 21 & $3.3(3.1-3.4)^{b}$ \\
\hline Grass $_{\mathrm{CW}}$ & 17 & $2.8(2.6-3.0)^{a}$ & 16 & $2.6(2.2-3.0)^{\mathrm{a}}$ & 17 & $2.9(2.7-3.1)^{a}$ \\
\hline
\end{tabular}

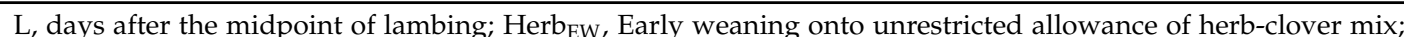
$\mathrm{Herb}_{\mathrm{CW}}$, lambs and dams offered an unrestricted allowance of herb-clover mix until conventional weaning age; Grass $_{\mathrm{CW}}$, lambs and dams offered unrestricted allowance of grass-predominant pasture until conventional weaning age. ${ }^{a-d}$ Means with different superscripts are significantly different within each year and treatments. In each year, ewes in Herb $b_{\mathrm{EW}}$ grazed with lambs and their ewes in Grass $\mathrm{CW}$. Ewes in Herb $\mathrm{CW}_{\mathrm{CW}}$ grazed with their lambs and the weaned lambs in the Herb $\mathrm{EW}_{\mathrm{W}}$ treatment.

\section{Discussion}

The aim of the present study was to determine the impact of weaning lambs early at a minimum live weight of $14 \mathrm{~kg}$, at $\sim 50$ days of age, onto a herb-clover mix, on the liveweight of lambs and ewes to a conventional weaning age compared to leaving lambs with their dams unweaned on a herb-clover mix or grass-predominant pasture. Overall, the lambs weaned early onto a herb-clover mix at a minimum live weight of $14 \mathrm{~kg}$ gained live weights similar to commercially-reared and conventionally-weaned twin lambs in New Zealand [18]. These results suggest that lambs can be weaned at a minimum of $14 \mathrm{~kg}$ live weight, at $~ 50$ days of age, provided a minimum pre-grazing cover of approximately $3000 \mathrm{~kg} \mathrm{DM} /$ ha of herb-clover mix, without impacting normal growth rates.

The liveweight gain of early-weaned lambs varied between years. In 2016, lambs weaned early onto a herb-clover mix were statistically $800 \mathrm{~g}$ lighter at conventional weaning age than lambs that remained with their dams on a grass-predominant pasture. While in 2017, lambs weaned early had similar liveweight gains and weaning weights compared to lambs unweaned on grass-predominant pasture resulting similar live weights at conventional weaning. This suggests that lambs weaned early onto a herb-clover mix have the potential to perform as similar as lambs unweaned on grass-predominant pasture at conventional weaning. The liveweight gain of early-weaned lambs in both years of the present study were similar to those previously reported for lambs weaned at a minimum live weight of $16 \mathrm{~kg}$, at approximately 60 days of age, onto a herb-clover mix [11,19].

The difference in growth rates between early-weaned lambs and unweaned lambs in 2016 and in 2017 , however, is of interest as it might indicate when early weaning onto a herb-clover mix is best utilized by farmers. It has been shown that when grass-predominant pasture masses were lower than $1200 \mathrm{~kg} \mathrm{DM} / \mathrm{ha}$, lamb growth rates were improved by early weaning onto a herb-clover mix [20]. In the present study, pasture mass of grass-predominant pasture was not limiting lamb growth [12], therefore, does not explain the variation of growth rates between early-weaned lambs and unweaned lambs.

In the present study, the nutritional quality of herb-clover mix and grass-predominant pastures differed between years. In 2016, when early-weaned lambs grew slower than unweaned lambs on grass-predominant pasture, ME of herb-clover mix was higher than grass-predominant pasture, while in 2017, when lamb growth did not differ from unweaned lambs on grass-predominant pasture, ME of herb-clover mix was lower than grass-predominant pasture. Combined this suggests that the variation 
of $\mathrm{ME}$ is not the reason for the observed differences of lambs liveweight gains between years. In both years of the study, the $\mathrm{CP}$ of herb-clover mix was greater than grass-predominant pasture at the start of the experiment but did not differ throughout the remainder of the study period. Although the $\mathrm{CP}$ of both herbages were at the lower end of that is required for lamb growth $(15 \%-18 \% \mathrm{CP})$ in both years [21]. The variation in the CP content of the herb-clover mix and grass-predominant pasture does not also explain the variable liveweight gains.

The botanical composition of herbage changed between years within the herbage types, resulting in variation in the availability of the different plant species in both the herb-clover mix and grass-predominant pasture. Lambs have been shown to preferentially select certain plant species when offered as cut-and-carried fresh forage [9] and under grazing [22], therefore, the variation of the botanical composition of herbage between years could have affected the overall lamb nutrient intake, thus their growth rates and their live weights at conventional weaning. The botanical composition of the herbages was determined using a quadrat-cut method and therefore, may not have reflected what accurately what the lambs actually consumed. In the future, to understand the potential causes of variation, studies should attempt to determine which plants the animals are choosing and then undertake herbage quality analysis based on this. Although the data available in the present study makes it is difficult to explain the variation of live weights at conventional weaning age over two years, the difference of lamb weights was only $800 \mathrm{~g}$ which is unlikely to have a significant impact on the overall production system. Further research, however, is required to identify conditions that allow early weaned lambs to grow consistently as fast as those unweaned lambs offered grass-predominant pasture.

In both years of the current study, unweaned lambs on herb-clover mix grew faster, and were heavier at conventional weaning, than lambs unweaned on grass-predominant pasture. This has also been reported in previous studies [3,11]. In addition, a greater milk production of twin and triplet-rearing ewes has been reported when grazing the herb-clover mix compared with grass-predominant pasture [1]. Therefore, the greater liveweight gain of unweaned lambs on herb-clover mix than on grass-predominant pasture in both years could have been due to higher milk production of ewes on herb-clover mix, resulting in greater lamb milk intake as well as increased herbage intake of lambs, through preferential selection of plant species [10], or a combination of all these variables. Unfortunately, in the current study, neither milk nor herbage intake of lambs was measured.

In both years of the current study, unweaned lambs on herb-clover mix had greater liveweight gains than early-weaned lambs. This was also found in previous studies [3,11]. Early-weaned lambs had access to only herbage post-weaning while unweaned lambs had access to both milk and herbage. This suggests that if there is enough herbage, lambs should be left with their dams on herb-clover mix to achieve the greatest growth rates. Early weaning onto an herb-clover mix, however, can allow farmers to graze lambs at much greater stocking density on herb-clover mix, if only a small area is available, which is a common scenario in New Zealand, and thus to improve pasture utilization efficiency.

Early weaned ewes had greater liveweight gains and BCS than unweaned ewes on grass-predominant pasture in both years. Early-weaned ewes were managed along with unweaned ewes and lambs on the grass-predominant pasture until conventional weaning age, thus suggesting that the greater live weight and BCS observed was due to the cessation of lactation, reducing the energy requirement of the ewe [23]. Both weaned and unweaned ewes on herb-clover mix had similar liveweight gains to conventional weaning in both years of the study. Early weaning, therefore, can be used as a technique to improve ewe live weights and potentially their future performance as live weight at breeding has a positive impact on ewe reproductive performance [24].

\section{Conclusions}

Lambs weaned early at a minimum live weight of $14 \mathrm{~kg}$, at $\sim 50$ days of age, onto a herb-clover mix have the potential to achieve similar liveweight gains as lambs unweaned on grass-predominant pasture. Early weaning can allow ewes to gain greater live weights and BCS compared to conventional 
weaning on grass-predominant pasture. However, further research is required to determine how a consistent lamb growth response can be achieved by early weaning onto an herb-clover mix.

Author Contributions: Conceptualization, L.J.E.; investigation and supervision, R.A.C.-T., L.M.C., P.R.K. and S.T.M.; writing-review and editing, L.J.E., R.A.C.-T., L.M.C., P.R.K. and S.T.M. All authors have read and agreed to the published version of the manuscript.

Funding: This research received funding from Beef and Lamb New Zealand, and Massey University.

Acknowledgments: The authors wish to thank D. Burnham and Keeble farm staff for their technical assistance.

Conflicts of Interest: The authors have no conflicts of interest with any financial organization regarding the material discussed in the manuscript.

\section{References}

1. Hutton, P.; Kenyon, P.; Bedi, M.; Kemp, P.; Stafford, K.; West, D.; Morris, S.T. A herb and legume sward mix increased ewe milk production and ewe and lamb liveweight gain to weaning compared to a ryegrass dominant sward. Anim. Feed. Sci. Technol. 2011, 164, 1-7. [CrossRef]

2. Corner-Thomas, R.; Kemp, P.; Morris, S.T.; Kenyon, P. Grazing alternative herbages in lactation increases the liveweight of both ewe lambs and their progeny at weaning. Anim. Prod. Sci. 2014, 54, 1741-1746. [CrossRef]

3. Corner-Thomas, R.; Cranston, L.M.; Kemp, P.; Morris, S.T.; Kenyon, P. The performance of single-rearing ewes and their lambs offered ryegrass pasture or herb-clover mix during lactation. N. Z. J. Agric. Res. 2017, 61, 67-80. [CrossRef]

4. Somasiri, S.C.; Kenyon, P.; Kemp, P.; Morel, P.C.H.; Morris, S.T. Mixtures of clovers with plantain and chicory improve lamb production performance compared to a ryegrass-white clover sward in the late spring and early summer period. Grass Forage Sci. 2015, 71, 270-280. [CrossRef]

5. Somasiri, S.C.; Kenyon, P.; Kemp, P.; Morel, P.; Morris, S.T. Effect of herb-clover mixes of plantain and chicory on yearling lamb production in the early spring period. Anim. Prod. Sci. 2016, 56, 1662. [CrossRef]

6. Kemp, P.; Kenyon, P.R.; Morris, S.T. The use of legume and herb forage species to create high performance pastures for sheep and cattle grazing systems. Rev. Bras. Zootec. 2010, 39, 169-174. [CrossRef]

7. Cranston, L.; Kenyon, P.; Morris, S.; López-Villalobos, N.; Kemp, P. Effect of post-grazing height on the productivity, population and morphology of a herb and legume mix. N. Z. J. Agric. Res. 2015, 58, 397-411. [CrossRef]

8. Waghorn, G.C.; Burke, J.L.; Kolver, E.S. Principles of feeding value. In Pasture and Supplements for Grazing Animals; Rattray, P., Brookes, I.M., Nicol, A., Eds.; New Zealand Society of Animal Production: Hamilton, New Zealand, 2007; pp. 35-39.

9. Pain, S.J.; Hutton, P.G.; Kenyon, P.R.; Morris, S.T.; Kemp, P.D. Preference of lambs for novel pasture herbs. Proc. N. Z. Soc. Anim. Prod. 2010, 70, 258-287.

10. Kerr, P. 400 Plus—A Guide to Improved Lamb Growth; New Zealand Sheep Council: Wellington, UK, 2000.

11. Ekanayake, W.E.M.L.J.; Corner-Thomas, R.A.; Cranston, L.M.; Kenyon, P.R.; Morris, S.T. A comparison of liveweight gain of lambs weaned early onto a herb-clover mixed sward and weaned conventionally onto a ryegrass-clover pasture and herb-clover mixed sward. Asian-Australas. J. Anim. Sci. 2018, 32, 201-208. [CrossRef] [PubMed]

12. Morris, S.T.; Kenyon, P. The effect of litter size and sward height on ewe and lamb performance. N. Z. J. Agric. Res. 2004, 47, 275-286. [CrossRef]

13. Nowak, R.; Poindron, P. From birth to colostrum: Early steps leading to lamb survival. Reprod. Nutr. Dev. 2006, 46, 431-446. [CrossRef] [PubMed]

14. Jefferies, B.C. Body condition scoring and its use in management. Tasmanian J. Agric. 1986, 32, $19-21$.

15. Frame, J. Herbage Mass. In Sward Measurement Handbook; Hodgson, J., Baker, R., Davies, D.A., Laidlaw, A.S., Leaver, J., Eds.; British Grassland Society: Hurley, UK, 1993; pp. 39-69.

16. Roughan, P.G.; Holland, R. Predicting in-vivo digestibilities of herbages by exhaustive enzymic hydrolysis of cell walls. J. Sci. Food Agric. 1977, 28, 1057-1064. [CrossRef]

17. Robertson, J.; Van Soest, P. The detergent system of analysis and its application to human foods. In The Analysis of Dietary Fiber in Food; James, W.P.T., Theander, O., Eds.; Marcel Dekker Inc.: New York, NY, USA, 1981; pp. 123-158. 
18. Litherland, A.J.; Lambert, M.G. Herbage quality and growth rate of single and twin lambs at foot. Proc. N. Z. Soc. Anim. Prod. 2000, 60, 55-57.

19. Corner-Thomas, R.; Cranston, L.M.; Kemp, P.; Morris, S.T.; Kenyon, P. Can herb-clover mixes compensate for the lack of milk in the diet of early-weaned lambs? N. Z. J. Agric. Res. 2018, 1-13. [CrossRef]

20. Ekanayake, W.E.M.L.J.; Corner-Thomas, R.A.; Cranston, L.M.; Kenyon, P.R.; Morris, S.T. The effect of live weight at weaning on liveweight gain of early weaned lambs onto a herb-clover mixed sward. Proc. N. Z. Soc. Anim. Prod. 2017, 77, 37-42.

21. Hodgson, J.; Brookes, I. Nutrition of grazing animals. In New Zealand Pasture and Crop Science; Hodgson, J., White, J., Eds.; Oxford University Press: Auckland, New Zealand, 2002; pp. 133-153.

22. Somasiri, S.C. Effect of Herb-Clover Mixes on Weaned Lamb Growth. Ph.D. Thesis, Massey University, Palmerston North, New Zealand, 2014.

23. Kenyon, P.R.; Webby, R.W. Pastures and supplements in sheep production systems. In Pasture and Supplements for Grazing Animals; Rattray, P., Brookes, I.M., Nicol, A., Eds.; New Zealand Society of Animal Production: Hamilton, New Zealand, 2007; pp. 255-274.

24. Corner-Thomas, R.; Ridler, A.; Morris, S.; Kenyon, P. Ewe lamb live weight and body condition scores affect reproductive rates in commercial flocks. N. Z. J. Agric. Res. 2015, 58, 26-34. [CrossRef]

(C) 2020 by the authors. Licensee MDPI, Basel, Switzerland. This article is an open access article distributed under the terms and conditions of the Creative Commons Attribution (CC BY) license (http://creativecommons.org/licenses/by/4.0/). 